\title{
Cerebrospinal fluid abnormalities in developmental and epileptic encephalopathy with a de novo CDK19 variant
}

Yuji Sugawara, MD, Tomoko Mizuno, MD, Kengo Moriyama, MD, Hisako Ishiwata, MD, Mitsuhiro Kato, MD, PhD, Mitsuko Nakashima, MD, PhD, Takeshi Mizuguchi, MD, PhD, and Naomichi Matsumoto, MD, PhD

Neurol Genet 2020;6:e527. doi:10.1212/NXG.0000000000000527

Developmental and epileptic encephalopathy (DEE) is a spectrum of neurodevelopmental conditions in which psychomotor delay or regression arises in association with frequent epileptic activity. In the past decade, molecular genetics studies showed that DEE is caused by environmental insults and by genetic factors; several de novo pathogenic variants were also identified. ${ }^{1}$

Recently, it was reported that de novo cyclin-dependent kinase 19 (CDK19 [MIM: 614720]) gene missense variants cause DEE in the early infantile period, such as infantile spasms (IS). ${ }^{2}$ The clinical characteristics of patients with CDK19 mutations consist of global developmental delay, intellectual disability, hypotonia, early onset epilepsy (including IS), and facial dysmorphism. Functional analyses have revealed that pathogenic CDK19 mutations cause the loss of the important function of CDK19 during neurodevelopment or synapse formation/function and underlie a syndromic neurodevelopmental disorder. Conversely, detailed biochemical and metabolic profiles have not been reported, and the mechanism underlying refractory epilepsy remains unknown.

Here, we report a case of DEE with a pathogenic CDK19 variant exhibiting distinct CSF abnormalities.

The index case is a 7-year-old girl born to nonconsanguineous healthy parents after an uneventful delivery. She exhibited global developmental delay since early infancy and onset of epileptic spasms and tonic seizures at 6 months of age. The diagnosis of IS was confirmed by hypsarrhythmia on interictal EEG. Biochemical and metabolic studies identified an elevated total protein content in the CSF (hyperproteinorrachia) (figure, A). At 12 months of age, her height, weight, and head circumference were $80.3 \mathrm{~cm}$ (99th percentile), $10.0 \mathrm{~kg}$ (88th percentile), and $44.6 \mathrm{~cm}$ (33rd percentile), respectively. She had distinct facial dysmorphism characterized by hypertelorism, a prominent nose with a bulbous tip, and a large mouth with widely spaced teeth. Neurologic assessment revealed severe developmental delay accompanied by global hypotonia. She was unable to control her head or track objects. Brain MRI revealed brain atrophy and white matter abnormalities (figure, B). Her epilepsy was refractory to conventional antiepileptic drugs and ketogenic diet. Brain atrophy and white matter abnormalities persisted in MRI at 3 years 7 months (figure, C). The CSF examinations performed at 3 years 8 months and at 3 years 11 months reproduced hyperproteinorrachia. Moreover, moderate elevation of glycine concentration in the CSF and plasma were identified (figure, A). The $\mathrm{CSF} /$ plasma glycine ratio was normal, and genetic testing for GLDC and AMT, the responsible

From the Department of Pediatrics (Y.S., T. Mizuno, K.M.), Tokyo Medical and Dental University, Yushima, Bunkyo-ku; Home Care Clinic for Children Aozora Sumida (H.I.), Higashikomagata, Sumida-ku, Tokyo; Department of Pediatrics (M.K.), Showa University School of Medicine, Hatanodai, Shinagawa-ku, Tokyo; Department of Human Genetics (M.N., T. Mizuguchi, N.M.), Yokohama City University Graduate School of Medicine, Fukuura, Kanazawa-ku, Yokohama; Department of Biochemistry (M.N.), Hamamatsu University School of Medicine, Handayama, Higashi-ku Hamamatsu; and Present Address: Department of Pediatrics (Y.S.), Soka Municipal Hospital, Soka, Soka-Shi, Saitama-Ken, Japan.

Go to Neurology.org/NG for full disclosures. Funding information is provided at the end of the article.

The Article Processing Charge was funded by the authors.

Ethics: The study protocol was approved by the institutional review board of the Faculty of Medicine, Yokohama City University, Japan. Written informed consent was obtained from the parents for the publication of this case report as per the hospital guidelines.

This is an open access article distributed under the terms of the Creative Commons Attribution-NonCommercial-NoDerivatives License 4.0 (CC BY-NC-ND), which permits downloading and sharing the work provided it is properly cited. The work cannot be changed in any way or used commercially without permission from the journal. 
Figure CSF profiles and brain MRI in the patient with a CDK19 variant

\begin{tabular}{|c|c|c|c|c|c|}
\hline Age & & 7 months & 8 months & $\begin{array}{l}3 \text { years, } \\
8 \text { months }\end{array}$ & $\begin{array}{l}3 \text { years, } \\
11 \text { months }\end{array}$ \\
\hline & Reference range & & & & \\
\hline CSF cell count $(/ \mu \mathrm{L})$ & $(0-8)$ & 0.67 & 0.0 & 1.0 & 1.0 \\
\hline CSF total protein $(\mathrm{mg} / \mathrm{dL})$ & $(15-40)$ & 66.7 & 151.4 & 67.0 & 59.0 \\
\hline CSF IgG (mg/dL) & $(0.5-4.0)$ & & & 10.3 & 8.7 \\
\hline IgG index & $(0.48-0.78)$ & & & 0.87 & 0.96 \\
\hline CSF glycine $(\mathrm{nmol} / \mathrm{mL})$ & $(<11)$ & & & 12.8 & 12.7 \\
\hline Plasma glycine (nmol/mL) & $(117-223)$ & 243.7 & & 507.1 & 509.3 \\
\hline CSF/plasma glycine ratio & $(0.01-0.04)$ & & & 0.025 & 0.025 \\
\hline
\end{tabular}

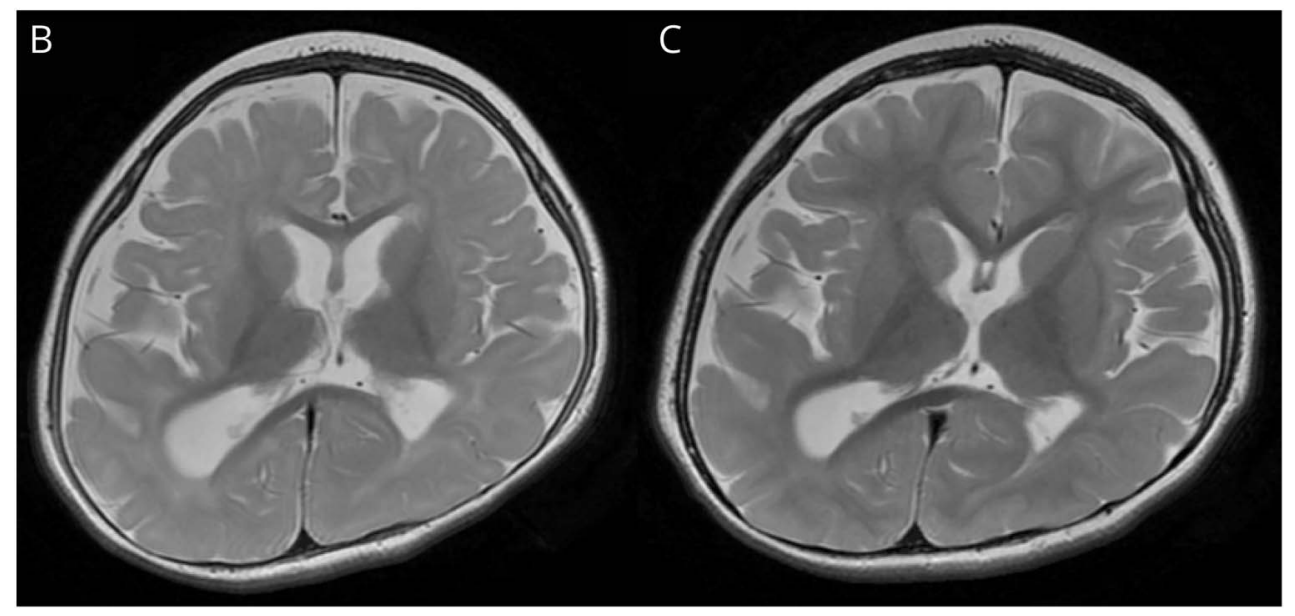

Biochemical and metabolic profiles in chronological order (A). The elevated total protein content in the CSF (hyperproteinorrachia) persisted, whereas a moderate elevation of glycine in the CSF and plasma was identified in the examinations performed subsequently. MRI axial T2-weighted sequences were acquired at 1 year 0 month (B) and 3 years 7 months (C). Nonprogressive brain atrophy was concomitant with white matter abnormalities that were suggestive of delayed myelination.

genes for nonketotic hyperglycinemia $(\mathrm{NKH})$, was negative. Oral dextromethorphan administration was initiated at 4 years of age but was unsuccessful. Finally, a de novo missense variant of CDK19 [NM_015076:c.94T>C, p.(Tyr32His)] that was pathogenic in a previous report ${ }^{2}$ was identified using trio-based whole-exome sequencing, as previously described. ${ }^{3}$ At 7 years of age, she continued to present seizures and remained profoundly disabled.

Our case exhibited the clinical presentation of DEE with CDK19 mutation and was characterized by global developmental delay, severe intellectual disability, profound hypotonia, early onset refractory epilepsy, and facial dysmorphism. ${ }^{2}$ Tall stature was also identified as another physical feature encountered in our case and 1 of the 3 patients in the previous report. Of note, these 2 cases with accelerated growth harbored the same missense variant, c.94T $>\mathrm{C}$ [p.Tyr32His], suggesting a genotypephenotype correlation. ${ }^{2}$

Distinct biochemical and metabolic abnormalities, i.e., hyperproteinorrachia and elevated glycine in the CSF and plasma, were also detected. The mechanism through which the CDK19 variant leads to the CSF abnormalities remains unknown. Although CDK19 and its paralog CDK8 are involved in transcription, ${ }^{4}$ it is not reported to date that the genes involved in glycine cleavage are regulated by CDK19/CDK8. On the other hand, it is important to elucidate the implication of these CSF abnormalities in the intractability of epilepsy in patients with a CDK19 variant. In particular, glycine serves as an excitation modulator of $\mathrm{N}$-methyl-D-aspartate (NMDA)-type glutamatergic receptors, and excessive activation of NMDA receptors by abnormally accumulated glycine in $\mathrm{NKH}$ results in neuronal damage and DEE. ${ }^{5}$ A recent study reported that early intervention was critical for the successful management of NKH by specific treatments, such as the oral administration of dextromethorphan, an NMDA receptor antagonist. ${ }^{6}$ In other DEE cases with a CDK19 variant, a complete metabolic assessment, including the analysis of amino acids in the CSF, and when elevated CSF glycine is reproduced in early infancy, the investigation of the possibility of adopting a specific treatment option are advised.

In summary, this second report of DEE with recurrent $C D K 19$ mutation expands its clinical spectrum and suggests that further investigations including biochemical and metabolic assessments are necessary to elucidate the pathophysiology of this specific DEE.

\section{Acknowledgment}

The authors are indebted to the patient and her parents. The authors would also like to thank Enago (enago.jp) for the English language review. 


\section{Study funding}

This work was supported by AMED under the grant numbers JP19lk0201069 (to M. Kato), JP20ek0109486, JP20dm0107090, JP20ek0109301, JP20ek0109348, and JP20kk0205012 (to N. Matsumoto); JSPS KAKENHI under the grant numbers JP 20K08236 (to M. Kato), JP20K08164 (to T. Mizuguchi), and JP17H01539 (to N. Matsumoto); MHLW Research program on rare and intractable diseases, Grant number JPMH20FC1039 (to M. Kato); Intramural Research Grants for Neurologic and Psychiatric Disorders of NCNP under the grant numbers 30-6 (to M. Kato and N. Matsumoto) and 30-7 (N. Matsumoto); and the Takeda Science Foundation (to T. Mizuguchi and N. Matsumoto).

\section{Disclosure}

The authors report no disclosures. Go to Neurology.org/NG for full disclosures.

\section{Publication history}

Received by Neurology: Genetics June 19, 2020. Accepted in final form August 31, 2020.

Appendix Authors

\begin{tabular}{lll}
\hline Name & Location & Contribution \\
\hline $\begin{array}{l}\text { Yuji } \\
\text { Mugawara, }\end{array}$ & $\begin{array}{l}\text { Tokyo Medical and Dental } \\
\text { University, Japan }\end{array}$ & $\begin{array}{l}\text { Acquired the clinical } \\
\text { data and drafted the } \\
\text { manuscript }\end{array}$ \\
$\begin{array}{l}\text { Tomoko } \\
\text { Mizuno, MD }\end{array}$ & $\begin{array}{l}\text { Tokyo Medical and Dental } \\
\text { University, Japan }\end{array}$ & $\begin{array}{l}\text { Acquired the clinical } \\
\text { data and revised the } \\
\text { draft }\end{array}$ \\
\hline
\end{tabular}

Appendix (continued)

\begin{tabular}{lll}
\hline Name & Location & Contribution \\
\hline $\begin{array}{l}\text { Kengo } \\
\text { Moriyama, }\end{array}$ & $\begin{array}{l}\text { Tokyo Medical and Dental } \\
\text { University, Japan }\end{array}$ & $\begin{array}{l}\text { Acquired the clinical } \\
\text { data and revised the } \\
\text { draft }\end{array}$ \\
\hline $\begin{array}{l}\text { Hisako } \\
\text { Ishiwata, MD }\end{array}$ & $\begin{array}{l}\text { Home Care Clinic for } \\
\text { Children Aozora Sumida, } \\
\text { Tokyo, Japan }\end{array}$ & $\begin{array}{l}\text { Acquired the clinical } \\
\text { data and revised the } \\
\text { draft }\end{array}$ \\
$\begin{array}{l}\text { Mitsuhiro } \\
\text { Kato, MD, PhD }\end{array}$ & $\begin{array}{l}\text { Showa University School of } \\
\text { Medicine, Tokyo, Japan }\end{array}$ & $\begin{array}{l}\text { Designed the study, } \\
\text { acquired funding, and } \\
\text { revised the draft }\end{array}$ \\
\hline $\begin{array}{l}\text { Mitsuko } \\
\text { Nakashima, } \\
\text { MD, PhD }\end{array}$ & $\begin{array}{l}\text { Yokohama City University } \\
\text { Graduate School of }\end{array}$ & $\begin{array}{l}\text { Analyzed the genetic } \\
\text { data and revised the } \\
\text { draft }\end{array}$ \\
\hline $\begin{array}{l}\text { Takeshi } \\
\text { Mizuguchi, } \\
\text { MD, PhD }\end{array}$ & $\begin{array}{l}\text { Yokohama City University } \\
\text { Graduate School of } \\
\text { Medicine, Japan }\end{array}$ & $\begin{array}{l}\text { Acquired funding, } \\
\text { analyzed the genetic } \\
\text { data, and revised the } \\
\text { draft }\end{array}$ \\
$\begin{array}{l}\text { Maomichi } \\
\text { Matsumoto, } \\
\text { MD, PhD }\end{array}$ & $\begin{array}{l}\text { Yokohama City University } \\
\text { Mraduate School of }\end{array}$ & $\begin{array}{l}\text { Designed the study, } \\
\text { acquired funding, and } \\
\text { revised the draft }\end{array}$ \\
\hline
\end{tabular}

\section{References}

1. He N, Lin ZJ, Wang J, et al. Evaluating the pathogenic potential of genes with de novo variants in epileptic encephalopathies. Genet Med 2019;21:17-27.

2. Chung H, Mao X, Wang H, et al. De novo variants in CDK19 are associated with a syndrome involving intellectual disability and epileptic encephalopathy. Am J Hum Genet 2020;106:1-9.

3. Sakamoto M, Kouhei D, Haniffa M, et al. A novel ITPA variant causes epileptic encephalopathy with multiple-organ dysfunction. J Hum Genet 2020;65:751-757.

4. Galbraith MD, Donner AJ, Espinosa JM. CDK8: a positive regulator of transcription. Transcription 2010;1:4-12.

5. Krawiec C, Goyal A. Nonketotic Hyperglycinemia. Treasure Island: StatPearls Publishing; 2020.

6. Bjoraker KJ, Swanson MA, Coughlin CR, et al. Neurodevelopmental outcome and treatment efficacy of benzoate and dextromethorphan in siblings with attenuated nonketotic hyperglycinemia. J Pediatr 2016;170:234-239. 


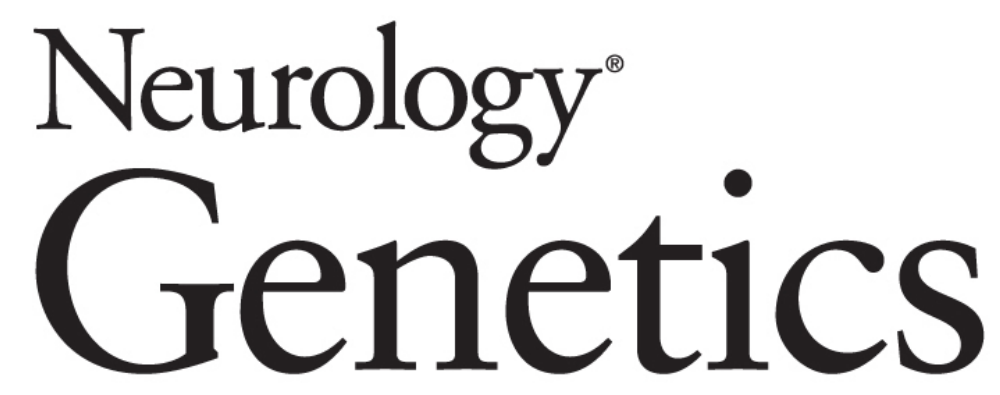

\section{Cerebrospinal fluid abnormalities in developmental and epileptic encephalopathy with a de novo CDK19 variant}

Yuji Sugawara, Tomoko Mizuno, Kengo Moriyama, et al.

Neurol Genet 2020;6;

DOI 10.1212/NXG.0000000000000527

This information is current as of October 8, 2020

\section{Updated Information \&} Services

References

Citations

Subspecialty Collections

Permissions \& Licensing

Reprints including high resolution figures, can be found at: http://ng.neurology.org/content/6/6/e527.full.html

This article cites 5 articles, 0 of which you can access for free at: http://ng.neurology.org/content/6/6/e527.full.html\#\#ref-list-1

This article has been cited by 1 HighWire-hosted articles: http://ng.neurology.org/content/6/6/e527.full.html\#\#otherarticles

This article, along with others on similar topics, appears in the following collection(s):

\section{All Genetics}

http://ng.neurology.org//cgi/collection/all_genetics

Infantile spasms

http://ng.neurology.org//cgi/collection/infantile_spasms

Information about reproducing this article in parts (figures,tables) or in its entirety can be found online at:

http://ng.neurology.org/misc/about.xhtml\#permissions

Information about ordering reprints can be found online:

http://ng.neurology.org/misc/addir.xhtml\#reprintsus

Neurol Genet is an official journal of the American Academy of Neurology. Published since April 2015, it is an open-access, online-only, continuous publication journal. Copyright Copyright @ 2020 The Author(s). Published by Wolters Kluwer Health, Inc. on behalf of the American Academy of Neurology.. All rights reserved. Online ISSN: 2376-7839.

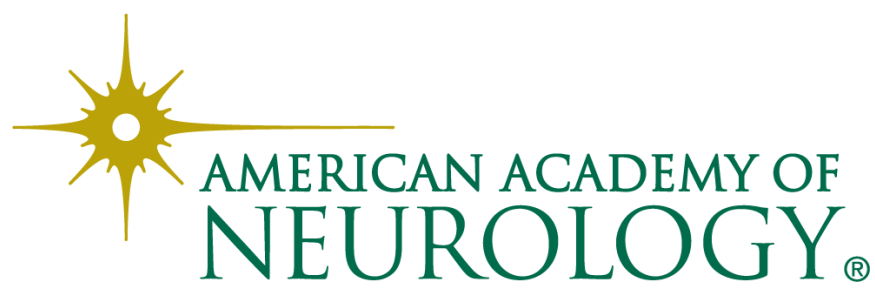

